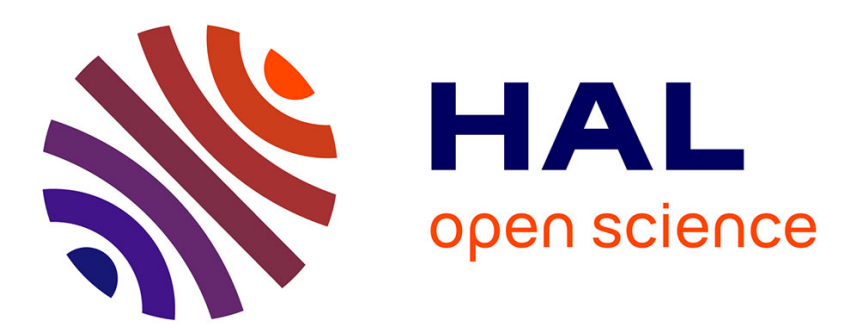

\title{
Occurence of Hymenoscyphus pseudoalbidus on infected ash logs
}

Claude Husson, Olivier Cael, Jean-Paul Grandjean, Louis-Michel Nageleisen, Benoit Marçais

\section{- To cite this version:}

Claude Husson, Olivier Cael, Jean-Paul Grandjean, Louis-Michel Nageleisen, Benoit Marçais. Occurence of Hymenoscyphus pseudoalbidus on infected ash logs. Plant Pathology, 2012, 61 (5), pp.889895. 10.1111/j.1365-3059.2011.02578.x . hal-01191345

\section{HAL Id: hal-01191345 \\ https://hal.science/hal-01191345}

Submitted on 12 Sep 2015

HAL is a multi-disciplinary open access archive for the deposit and dissemination of scientific research documents, whether they are published or not. The documents may come from teaching and research institutions in France or abroad, or from public or private research centers.
L'archive ouverte pluridisciplinaire HAL, est destinée au dépôt et à la diffusion de documents scientifiques de niveau recherche, publiés ou non, émanant des établissements d'enseignement et de recherche français ou étrangers, des laboratoires publics ou privés. 


\title{
Occurrence of Hymenoscyphus pseudoalbidus on infected ash logs
}

\author{
C. Husson ${ }^{a \star}$, O. Caël ${ }^{\mathrm{a}}$, J. P. Grandjean ${ }^{\mathrm{b}}$, L. M. Nageleisen ${ }^{\mathrm{c}}$ and B. Marçais ${ }^{\mathrm{a}}$ \\ aINRA, Nancy Université, UMR 1136 Interactions Arbres/Microorganismes, IFR 110, F-54280 Champenoux; ' ONF, Direction \\ territoriale Franche-Comté, Département Santé des Forêts, 1 Chemin du Faulot, F-70800 Ainvelle; and 'Département de la Santé des \\ Forêts, Antenne Spécialisée, F-54280 Champenoux, France
}

Ash decline induced by Hymenoscyphus pseudoalbidus is an emerging disease that severely affects Fraxinus excelsior stands in Europe. There has been an invasive spread of the disease from east to west in Europe over the last decade. Wood discoloration on infected trunks has been reported, but few data are available on the involvement of H. pseudoalbidus in such symptoms. Transport and trade of ash logs could introduce the pathogen into disease-free areas and therefore accelerate its dissemination. The aim of this study was to assess the prevalence and severity of H. pseudoalbidus in ash logs in infested areas located in the northeast of France and to clarify the role of secondary pathogens in ash decline. The results showed that prevalence of $H$. pseudoalbidus on collar lesions was high in the study area. The pathogen was able to produce conidia from infected wood. Thus, export of ash logs could represent a potential risk for spreading the disease. Involvement of Armillaria spp. in the decline process was confirmed, while no Phytophthora-induced collar lesions were found. Studying both disease prevalence and the age of callus tissues surrounding collar lesions in 60 ash stands enabled the origin of the disease in the study area to be determined.

Keywords: canker, collar, emerging disease, Hymenoscyphus pseudoalbidus, lesions, quarantine pathogen

\section{Introduction}

Since the early 1990s, an emerging lethal disease has reached epidemic levels on ash in Central Europe (Kowalski, 2006; Bakys et al., 2009). The causal agent, Hymenoscyphus pseudoalbidus (anamorph Chalara fraxinea), first described in Poland, is responsible for a severe decline on all age classes of Fraxinus excelsior and F. angustifolia trees (Kowalski \& Holdenrieder, 2008; Kirisits et al., 2010; Queloz et al., 2011). Main symptoms described are brownish to orange bark necroses and cankers without exudates on shoots, stems and branches, leading to wilting of the leaves and dieback of the trees (Kowalski, 2006; Kowalski \& Holdenrieder, 2009a; Schumacher et al., 2010).

Ash dieback could represent a serious threat to forest and nursery ash trees, and for this reason the European Plant Protection Organization (EPPO) Secretariat decided to add H. pseudoalbidus to the EPPO Alert List in 2007 (EPPO, 2010). Up to now, this invasive pathogen has not been reported on the west coast of Europe or outside of Europe. Although precise data are lacking on the biology of the fungus, trees for planting and infected

*E-mail: claude.husson@nancy.inra.fr

Published online 16 January 2012
F. excelsior logs are likely pathways for spreading the disease over long distances (EPPO, 2010). In France, disease emergence is very recent, as the first $H$. pseudoalbidus associated ash declines were observed in 2008 (Ioos et al., 2009). The disease is mainly located in northern and northeastern France where severe decline of F. excelsior stands has been observed (Husson et al., 2011). The west coast and southern France, where F. excelsior as well as $F$. angustifolia are well established, are still free of $H$. pseudoalbidus and keeping the region disease-free as long as possible is important. Spread of $H$. pseudoalbidus by infected ash logs needs to be better documented as massive logging is occurring in affected stands of eastern France and their transport and trade could introduce the pathogen to disease-free areas. For example, in Europe, phytosanitary measures including the treatment of imported oak logs by fumigation have been taken in order to prevent the introduction of Ceratocystis fagacearum, the causal agent of oak wilt, from North America (Desprez-Loustau, 2009). However, the frequency of $H$. pseudoalbidus presence on affected ash trees is not well documented. Although wood discoloration on mature tree trunks as well as root and butt rot have been reported, mostly on highly infected ash trees (Kowalski \& Holdenrieder, 2008; Skovsgaard et al., 2010; Bakys et al., 2011), few data are available about their prevalence, and involvement of $H$. pseudoalbidus in such symptoms remains unknown. Armillaria spp. were in fact the most abundant fungi isolated from trees with these 
types of symptoms, and were associated with the decline process as secondary pathogens (Skovsgaard et al., 2010; Bakys et al., 2011). Moreover, other potentially pathogenic fungi of the genera Cytospora, Diplodia, Fusarium and Phomopsis also colonized declining ashes (Lygis et al., 2005), as well as Phytophthora species (Orlikowski et al., 2011).

The aims of this study were therefore (i) to study the presence of $H$. pseudoalbidus on infected mature F. excelsior logs, with a particular focus on the collar; (ii) to estimate the prevalence and severity of necrotic lesions on collars or trunks of affected mature trees in a large area where intensive ash decline has been observed; and (iii) to clarify the role of other pathogens such as Phytophthora spp. or Armillaria spp. in the F. excelsior decline process.

\section{Material and methods}

\section{Sampling procedure on infected trees}

In March and May 2010, 10 trees with symptoms (with a trunk diameter of $15-20 \mathrm{~cm}$ at $1.3 \mathrm{~m}$ height) were selected from five highly infested plots located in northeastern France and felled. The overall health status of the trees was rated before felling as follows: 1 , slightly declining; 2 , moderately declining; 3 , severely declining. Then, $5 \mathrm{~cm}$ thick wood disks were collected from collars, trunks and branches using a chain saw, and symptoms were observed on each part of the trees (Table 1). The disks were sampled on the bole every 1-2 $\mathrm{m}$ and wherever potential symptoms of $H$. pseudoalbidus such as wood discoloration or infected sprouts were present. Infected shoots from the crown or sprouts from trunks were also sampled. The samples were placed in plastic bags and brought back to the laboratory for analysis. In addition, the status of collars and roots was investigated. Soil was removed around major roots of three trees that exhibited collar lesions out of the 10 trees felled (approximately $10-20 \mathrm{~cm}$ deep and $50-100 \mathrm{~cm}$ long) and sections of major roots were sampled.

\section{Production of conidia and isolation of H. pseudoalbidus from necrotic ash disks}

Wood disks with discoloration collected from the collar of four out of the 10 trees and from major roots of one ash tree were split using a steel wood chisel, placed in plastic boxes on moist paper towels using sterile water and

Table 1 Characteristics of the Fraxinus excelsior trees studied and results of the PCR analysis

\begin{tabular}{|c|c|c|c|c|c|c|c|c|c|}
\hline \multirow[b]{2}{*}{ Tree } & \multirow[b]{2}{*}{ Stand } & \multirow[b]{2}{*}{ Location } & \multirow{2}{*}{$\begin{array}{l}\text { Decline status } \\
\text { assessed } \\
\text { before fall }\end{array}$} & \multicolumn{2}{|l|}{ Collar } & \multicolumn{2}{|l|}{ Trunk } & \multicolumn{2}{|l|}{ Crown } \\
\hline & & & & Symptom & PCR & Symptom & PCR & Symptom & PCR \\
\hline 3 & 6 & Mersuay & 1 & Bark lesion & + & $\begin{array}{l}\text { No symptom } \\
\text { (healthy wood sampled) }\end{array}$ & - & Infected shoots & - \\
\hline 7 & 41 & Mersuay & 1 & No lesion & NT & $\begin{array}{l}\text { No symptom } \\
\text { (healthy wood sampled) }\end{array}$ & - & Infected shoots & + \\
\hline \multirow[t]{2}{*}{1} & \multirow[t]{2}{*}{1} & \multirow[t]{2}{*}{ Ainvelle } & \multirow[t]{2}{*}{2} & \multirow[t]{2}{*}{ Bark lesion } & \multirow[t]{2}{*}{-} & Infected sprouts & - & $\begin{array}{l}\text { Canker, major } \\
\text { branches dead }\end{array}$ & + \\
\hline & & & & & & $\begin{array}{l}\text { Discoloration in heartwood } \\
\text { (pruning ?) }\end{array}$ & - & Infected shoots & + \\
\hline \multirow[t]{3}{*}{2} & \multirow[t]{3}{*}{1} & \multirow[t]{3}{*}{ Ainvelle } & \multirow[t]{3}{*}{2} & \multirow[t]{3}{*}{ Bark lesion } & \multirow[t]{3}{*}{+} & Bark beetle galleries & & \multirow{3}{*}{$\begin{array}{l}\text { Crown completely } \\
\text { dead }\end{array}$} & \multirow[t]{3}{*}{ NT } \\
\hline & & & & & & $\begin{array}{l}\text { Bark lesions at the foot } \\
\text { of infected sprouts }\end{array}$ & - & & \\
\hline & & & & & & $\begin{array}{l}\text { Discoloration in heartwood } \\
\text { (pruning ?) }\end{array}$ & - & & \\
\hline 4 & 6 & Mersuay & 2 & No lesion & NT & $\begin{array}{l}\text { Bark lesions at the foot of } \\
\text { infected sprouts at } 6 \mathrm{~m} \\
\text { high }\end{array}$ & + & $\begin{array}{l}\text { Canker, major } \\
\text { branches dead } \\
\text { Infected shoots }\end{array}$ & $\begin{array}{l}+ \\
+\end{array}$ \\
\hline 5 & 6 & Mersuay & 2 & Bark lesion & + & $\begin{array}{l}\text { No symptom } \\
\text { (healthy wood sampled) }\end{array}$ & - & Infected shoots & + \\
\hline 6 & 6 & Mersuay & 2 & Bark lesion & + & $\begin{array}{l}\text { Bark lesions at the foot of } \\
\text { infected sprouts at } \\
3 \mathrm{~m} \text { high }\end{array}$ & + & Infected shoots & + \\
\hline 8 & Hedge & Faverney & 3 & No lesion & NT & $\begin{array}{l}\text { Bark lesions } \\
\text { (due to wound ?) } \\
\text { at } 1.5 \mathrm{~m} \text { high }\end{array}$ & + & Infected shoots & - \\
\hline 9 & 33 & Mersuay & 3 & Bark lesion & - & $\begin{array}{l}\text { Discoloration in } \\
\text { heartwood }\end{array}$ & - & Infected shoots & + \\
\hline 10 & 33 & Mersuay & 3 & $\begin{array}{l}\text { Discoloration } \\
\text { in heartwood }\end{array}$ & - & $\begin{array}{l}\text { Discoloration in } \\
\text { heartwood }\end{array}$ & - & $\begin{array}{l}\text { Canker, major } \\
\text { branches dead }\end{array}$ & + \\
\hline & & & & & & & & Infected shoots & + \\
\hline
\end{tabular}

${ }^{2}$, slighlty declining, presence of sprouts in the crown; 2 , moderately declining, presence of sprouts on the trunk; 3 , severely declining NT, not tested. 
incubated at $20^{\circ} \mathrm{C}$ under a $16: 8 \mathrm{~h}$ light:dark regime. Disks were checked daily using a binocular microscope, mainly at the discoloration margin, and putative H. pseudoalbidus phialides and conidia produced on sapwood were collected and transferred into a $2 \mathrm{~mL}$ Eppendorf tube as soon as observed.

Isolation of $H$. pseudoalbidus from lesions was undertaken as described by Kowalski (2006). Briefly, 1-2 cm long pieces of wood containing the lesion margin were surface sterilized ( $1 \mathrm{~min}$ in $90 \%$ ethanol, $5 \mathrm{~min}$ in $4 \%$ $\mathrm{NaOCl}$ and $30 \mathrm{~s}$ in $90 \%$ ethanol) and then cut into small pieces. Pieces of wood were plated on malt agar supplemented with antibiotic $\left(20 \mathrm{~g} \mathrm{~L}^{-1}\right.$ malt extract, $100 \mathrm{mg} \mathrm{L}^{-1}$ streptomycin and $15 \mathrm{~g} \mathrm{~L}^{-1}$ agar). The Petri dishes were incubated at $20^{\circ} \mathrm{C}$ in the dark and any isolate morphologically similar to $H$. pseudoalbidus that emerged from the wood was transferred onto a new malt agar Petri dish.

\section{DNA extraction}

The presence of cankers or discoloration in sapwood/heartwood was recorded for each sampled wood disk. Whenever the presence of $H$. pseudoalbidus was suspected, a sample was taken for analysis. Pieces of wood at the margin of discoloured areas were cut using a hammer and a steel wood chisel. To avoid contamination, latex gloves were used during the handling of the disks and changed between samples. The chisels were sterilized by dipping for $5 \mathrm{~min}$ in $5 \% \mathrm{NaOCl}, 60 \mathrm{~s}$ in $70 \%$ ethanol and finally flamed. Approximately $100 \mathrm{mg}$ of these sapwood/heartwood samples were then collected with a rounded sterile scalpel blade and placed in a $2 \mathrm{~mL}$ Eppendorf tube. Healthy heartwood/sapwood pieces sampled in areas without discoloration were also collected as negative controls.

DNA extractions from wood were performed using the DNeasy Plant mini-kit (QIAGEN). Samples placed in a $2 \mathrm{~mL}$ Eppendorf tube were cooled to $-20^{\circ} \mathrm{C}$ for $10 \mathrm{~min}$ and then ground for $30 \mathrm{~s}$ with one $3 \mathrm{~mm}$ tungsten carbide bead at a frequency of $30 \mathrm{~Hz}$, using a mixer mill grinder (TissueLyser, QIAGEN). Four hundred microlitres of DNeasy ${ }^{\circledR}$ lysis buffer (AP1) and $400 \mu \mathrm{L}$ of powdered skimmed milk ( $8 \mathrm{~g} \mathrm{~L}^{-1}$ distilled water) were added and tubes were ground once again for $30 \mathrm{~s}$. DNA extractions were then performed following the manufacturer's instructions except that the incubation period with AP1 buffer at $65^{\circ} \mathrm{C}$ was extended to $60 \mathrm{~min}$. DNA was finally eluted in $150 \mu \mathrm{L}$ elution buffer. DNA extractions from phialides/conidia or mycelia from culture were performed following the manufacturer's instructions without modification.

\section{Real-time PCR amplifications}

Amplifications with the species-specific primer pairs and probe Cfrax-F/-R/-P for H. pseudoalbidus (Ioos et al., 2009; Husson et al., 2011) were performed in $15 \mu \mathrm{L}$ reaction volumes using the qPCR core kit No ROX (Eurogen- tec) and consisting of ultrapure water, $1 \times$ reaction buffer, $5 \mathrm{mM} \mathrm{MgCl}_{2}, 4 \times 0.2 \mathrm{~mm}$ dNTPs, $0.3 \mu \mathrm{M}$ of each primer, $0 \cdot 1 \mu \mathrm{M}$ of dual-labelled probe, $0 \cdot 15 \mathrm{U}$ of uracil-DNAglycosylase (UNG), $0.375 \mathrm{U}$ of HotGoldStar and $2 \mu \mathrm{L}$ of template DNA.

Real-time PCR reactions were carried out on a RotorGene 6200 (QIAGEN). The PCR cycling conditions included an initial step for UNG activation for $2 \mathrm{~min}$ at $50^{\circ} \mathrm{C}$, a HotGoldStar activation step for $10 \mathrm{~min}$ at $95^{\circ} \mathrm{C}$, followed by 35 cycles of denaturation at $95^{\circ} \mathrm{C}$ for $15 \mathrm{~s}$, and annealing and elongation at $65^{\circ} \mathrm{C}$ for $55 \mathrm{~s}$. The $C_{t}$ value for each reaction was determined using the RotorGene software version 1.7.75 with a normalized fluorescence set at $0 \cdot 02$.

\section{Survey procedures}

A survey to estimate the frequency of collar lesions on ash was conducted in summer 2010. Sixty plots were selected randomly in northeastern France in an area where severe decline associated with $H$. pseudoalbidus has been reported. In each plot, location was recorded using global positioning system equipment and 50 10-25 m high F. excelsior trees were randomly selected, except for seven plots where 100 trees were selected. The average height of trees, their origin (plantation versus regeneration originating from natural seeding), and the vegetation type (moist versus dry or mesic) were recorded. For each tree, the decline status of the crown (percentage of affected crown), except for eight out of 60 plots, and the lesion size on the collar (percentage of affected collar circumference) were recorded. The rating scale for both symptoms was as follows: $0=$ less than $5 \% ; 1=6-25 \%$; $2=26-50 \% ; 3=51-75 \% ; 4=76-100 \%$. Moreover, callus tissues surrounding the collar lesion of diseased trees were observed in order to estimate the age of lesions by counting the number of annual wood rings in the callus.

Thirty plots out of the 60 studied were investigated more precisely in order to collect samples and to check the presence of H. pseudoalbidus, Phytophthora spp. and Armillaria spp. Two to three trees per plot that exhibited collar lesions were selected and pieces of necrotic inner bark were collected at the lesion margin, placed in a $2 \mathrm{~mL}$ Eppendorf tube and brought back to the laboratory for analysis. Whenever mycelial fans of Armillaria spp. were observed in the affected collar tissues, they were sampled as well. Wood samples were assayed for the presence of H. pseudoalbidus using the DNA extraction method and real-time PCR test as described above. Isolation of Phytophthora spp. from lesion margins was performed as follows: pieces of wood collected at the lesion margin were quickly surface sterilized with $70 \%$ ethanol and plated on Phytophthora-selective PARBHY medium (Robin et al., 1998). Petri dishes were observed daily until 15 days after isolation. Finally, DNA from Armillaria mycelial fans collected on tree collars was extracted using the DNeasy Plant mini-kit. Species identification was then performed by PCR-RFLP analysis of the IGS region of ribosomal 
DNA (Harrington \& Wingfield, 1995) or by sequencing the IGS region. Isolates of $A$. cepistipes, A. gallica, A. mellea and A. ostoyae provided by J. J. Guillaumin were used as reference.

As crown status and collar lesion severity were rated with semi-quantitative ratings, the correlation between both variables was studied with Spearman correlation. Factors affecting the severity of collar lesions were studied by a multivariate analysis of variance. The dependent variable was the collar lesion size while independent variables all included as fixed effect were tree height, stand origin (planting or natural regeneration) and vegetation type. As a spatial pattern in severity was suspected, linked to the invasive nature of the disease, stand latitude and longitude were also included as confounding factors, i.e. factors that could strongly affect the response variable and induce spurious correlations. The significance level was set at $P<0.05$.

\section{Results}

Presence of $H$. pseudoalbidus on the bole of felled ash trees

Typical symptoms of $H$. pseudoalbidus decline were widely present in the crown of all 10 trees felled. Bark lesions and/or discoloration of the wood at the trunk or collar level were found on nine out of the 10 trees (Table 1). Three types of symptoms were observed at the trunk level: (i) heartwood/sapwood brownish discoloration, cambium being healthy, associated or not with old pruning wound (four trees); (ii) small bark lesions (5$10 \mathrm{~cm}^{2}$ area) located at $1-5 \mathrm{~m}$ height either at the base of infected sprouts (three trees) or associated with wounds (one tree); and (iii) large brownish bark lesions on the collar (six trees) which progress towards sapwood and heartwood leading to triangle-shaped discoloration, lesions being more extensive in inner bark. Similar lesions were observed on major roots of trees that exhibited collar symptoms. No sprouts were observed in the tree collar area. In addition, major roots of three observed trees that had lesions on the collar exhibited large necrotic tissues mainly located on the upper part of roots in contact with collar lesions. All size classes of roots were found to be infected, the finest often being dead. Finally, bark beetle attacks due to Leperesinus fraxinus were observed on the trunk of three of the trees studied.

Hymenoscyphus pseudoalbidus was present on all 10 of the sampled trees according to the PCR test (Table 1). However, positive detections were highly dependent on type of symptom (Table 2). The pathogen was never detected in discolorations located only in heartwood/sapwood. Hymenoscyphus pseudoalbidus was detected in small bark lesions on trunks linked to infected sprouts or associated with wounds (three out of four trees) and in large bark lesions located on the collar (four out six trees) and on major roots, and that affected both sapwood and heartwood. Samples collected on infected shoots in the crown were positive for seven out of the 10 trees studied. The three trees negative for H. pseudoalbi$d u s$ in the crown had drastically infected crowns with mostly dead branches or shoots. Finally, H. pseudoalbi$d u s$ was never detected from samples collected in healthy heartwood/sapwood (negative control).

\section{Production of conidia and isolation of H. pseudoalbidus from necrotic ash disks}

Detection of $H$. pseudoalbidus was confirmed from sapwood pieces of the five analysed necrotic disks (four from collar and one from root) by using the PCR test. Phialides typical of $H$. pseudoalbidus were observed using a binocular microscope on two out of four disks collected from the collar and on the one collected from the root after an

Table 2 Detection of Hymenoscyphus albidus on log disks of ash (Fraxinus excelsior) using real-time PCR assays (loos et al., 2009)

\begin{tabular}{|c|c|c|c|c|c|}
\hline Part of tree & $\begin{array}{l}\text { Location of samples } \\
\text { collected on log disk }\end{array}$ & Type of lesion ${ }^{a}$ & $\begin{array}{l}\text { Number of } \\
\text { samples tested }\end{array}$ & $\begin{array}{l}\text { Number of } \\
\text { positive detections }\end{array}$ & Percentage \\
\hline \multirow[t]{4}{*}{ Collar } & Heartwood & No lesion & 1 & 0 & 0 \\
\hline & Heartwood & Central & 1 & 0 & 0 \\
\hline & Sapwood & Periphery & 2 & 0 & 0 \\
\hline & Sapwood & Bark & 21 & 8 & 38 \\
\hline \multirow[t]{4}{*}{ Trunk } & Heartwood & No lesion & 21 & 0 & 0 \\
\hline & Heartwood & Central & 23 & 0 & 0 \\
\hline & Sapwood & Periphery & 5 & 0 & 0 \\
\hline & Sapwood & Bark & 8 & 3 & 44 \\
\hline \multirow{4}{*}{$\begin{array}{l}\text { Branches in } \\
\text { lower part } \\
\text { of crown }\end{array}$} & Heartwood & No lesion & 6 & 0 & 0 \\
\hline & Heartwood & Central & 2 & 0 & 0 \\
\hline & Sapwood & Periphery & 2 & 0 & 0 \\
\hline & Sapwood & Bark & 3 & 1 & 33 \\
\hline \multirow{2}{*}{$\begin{array}{l}\text { Branches } \\
\text { in crown }\end{array}$} & Sapwood & No lesion & 2 & 0 & 0 \\
\hline & Sapwood & Bark & 22 & 14 & 64 \\
\hline
\end{tabular}

${ }^{a}$ Central: located in heartwood; periphery: located at the periphery of disk without contact with cambium; bark: located from bark to sapwood/heartwood. 
incubation period of 5-7 days in a humid chamber. The pathogen was isolated on selective media from lesions located in sapwood of these three positive disks. Positive real-time PCR assays using species-specific primers and probe confirmed that both phialides/conidia and mycelium from culture were of $H$. pseudoalbidus.

\section{Prevalence of collar lesions in the surveyed area}

Altogether, 3350 trees located in 60 plots were observed for the presence of collar lesions, of which 2400 trees were also assessed for crown decline status. Collar lesions were found on $33.4 \%$ of the trees and on $95 \%$ of plots $(57$ out of 60$)$. The mean percentage of affected collar circumference was $20 \cdot 6 \pm 0 \cdot 8 \%$. Eighty-eight percent of trees had a decline status of the crown higher than $5 \%$. Only $8 \%$ of ash trees were healthy, i.e. without bark lesions and with decline status less than $5 \%$. This percentage decreased to $2.6 \%$ in the northeastern part of the study area. Overall, the crown status and the severity of collar lesions were significantly correlated (Spearman $r=0.271, P<0.001)$, but this relationship was highly dependent on the plots (Fig. 1). While correlation between collar lesion severity and crown decline was significant in the most severely affected stands, this was not true in less affected stands.

Samples from tree collars with symptoms were collected in 27 plots out of the 30 investigated. The presence of $H$. pseudoalbidus on the collar was confirmed by PCR assays on 26 of the sampled plots $(96 \%)$. The pathogen was detected on 45 out of 51 trees sampled ( $88 \%$ ). In contrast, Phytophthora spp. were never isolated on media from bark lesions. Armillaria spp. were very frequent within the ash collar lesions. Indeed, 70 out of 74 trees with symptoms (95\%) exhibited typical mycelial fans in the inner bark and cambial zone. Mycelial fans of Armil-

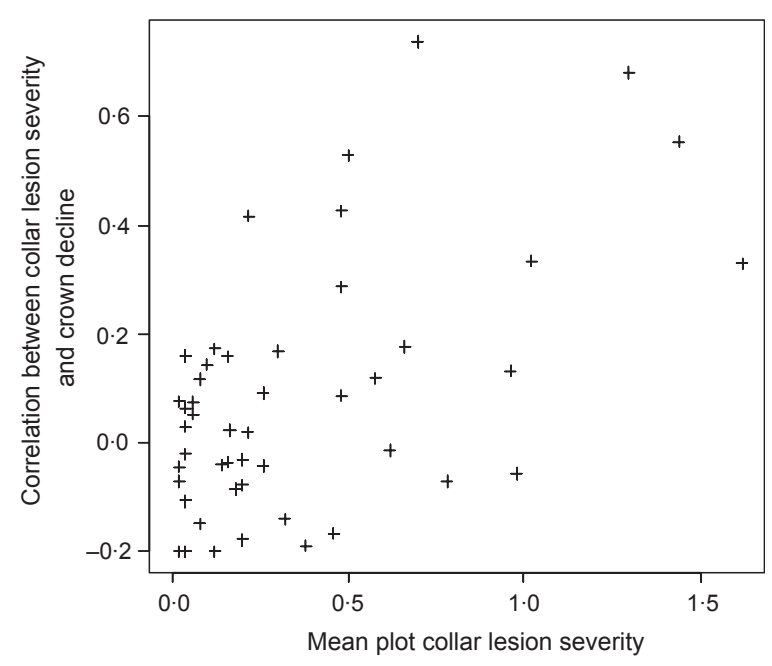

Figure 1 Spearman correlation between the collar lesion severity and decline status of the crown of Fraxinus excelsior caused by Hymenoscyphus pseudoalbidus, according to plot collar lesion severity. laria spp. were present in all but one infested plot which was ancient agricultural land where no epiphytic rhizomorph was found on tree collars. In addition, attacks of Armillaria spp. were never observed in H. pseudoalbidusfree plots, i.e. three out of the 30 studied. PCR-RFLP or IGS sequencing methods allowed identification of A. gallica, A. mellea and A. cepistipes in 27, four and two plots, respectively.

The prevalence of collar lesions on ash increased from the southwest $(20.5 \%$ of the observed trees) to the northeast $(47 \%)$ of the study area. Moreover, the collar lesion severity was higher in the northeastern area (Fig. 2a). The latitude and longitude of plots were indeed positively correlated with the affected collar circumference (Table 3). The size of collar lesions was significantly higher in young ash stands and in high moisture level plots (Table 3). In contrast, no significant difference was found between the two different origins of ash stand (plantation versus regeneration).

Finally, trees that exhibited collar lesions with callusing older than 1 year old were rare in the study area $(3 \%)$. However, they were more common in the northeast than in the southwest (31 and two trees, respectively; Fig. 2b). Three-year-old callusing (i.e. lesions formed in 2007) were observed in stands located in the northeast.

\section{Discussion}

The epidemiological survey revealed that infection of ash collars by $H$. pseudoalbidus was considerable both in terms of severity and prevalence. On average about a fifth of the collar circumference was affected in the ash population of the study area. Although these infection symptoms are very similar to Phytophthora-induced collar lesions, i.e. dark flame-shaped necroses in the inner bark, no Phytophthora was detected, while H. pseudoalbidus was consistently detected and therefore clearly involved in the lesion induction. The results confirm those of previous studies, which concluded that Phytophthora species were unlikely to be involved in the disease process (Bakys et al., 2009; Schumacher et al., 2010). Based on
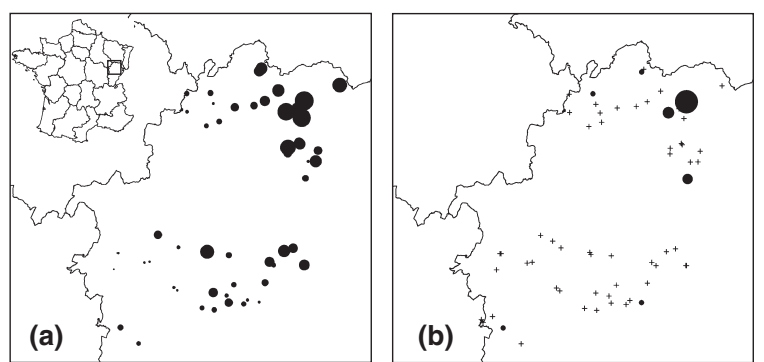

Figure 2 (a). Mean rating of collar lesion severity. • 0.01, •, 0.1, 1 , ratings range from 0 (less than $5 \%$ of affected collar circumference) to 4 (from 76 to $100 \%$ affected collar circumference); (b). Prevalence of trees with old collar lesions (callus tissues surrounding the lesion over 1 year old). + Absent, • $0 \cdot 1 \%$, 
Table 3 Multivariate analysis of variance of factors affecting collar lesion severity (percentage of affected collar circumference) caused by Hymenoscyphus pseudoalbidus

\begin{tabular}{lllrl}
\hline Factor & df & Mean square & $F$ value & $P$ value \\
\hline Tree height & 1 & 0.824 & 5.031 & 0.029 \\
Origin & 1 & 0.198 & 1.211 & 0.276 \\
Soil moisture & 1 & 1.713 & 10.455 & 0.002 \\
Longitude & 1 & 1.719 & 10.488 & 0.002 \\
Latitude & 1 & 0.842 & 5.137 & 0.028 \\
\hline
\end{tabular}

observations of wood disks, H. pseudoalbidus initially attacks inner bark where the lesions were more extensive and then progresses towards sapwood and then heartwood, gradually decreasing in size. The high prevalence of $H$. pseudoalbidus-induced collar lesions in the study area $(33 \%)$ is quite surprising as these symptoms were not widely reported in the literature, and the emergence of ash decline was reported more recently in France than in eastern Europe where the disease was first described (Kowalski, 2006). It is likely that H. pseudoalbidus was directly involved in root and stem base lesion induction described in previous studies carried out throughout Europe (Lygis et al., 2005; Skovsgaard et al., 2010; Bakys et al., 2011; Orlikowski et al., 2011). This collar infection probably plays a prominent role in the sudden decline and mortality of mature ashes in eastern France, as severity of collar lesions and decline status were significantly correlated in the severely affected stands.

Although the pathogen was detected in all parts of trees (from roots, collars, trunks, branches and shoots), H. pseudoalbidus does not appear to be a vascular pathogen. Indeed, no connection was observed between collar or branch lesions and trunk lesions and the pathogen was never detected in symptomless heartwood or sapwood samples using PCR assays. In addition, trunk lesions were mostly observed in the vicinity of infected sprouts or wounds. Therefore, the observed infection pattern probably arose from multiple separate infection events. Contrary to observations on trunks, bark lesions on collars did not appear to be linked to the presence of infected sprouts at the tree base. More likely, collar and major aerial root infections are induced by ascospores that might be able to infect the stem base via lenticels in the bark. Indeed, apothecia were observed in abundance on ash rachis present in the litter in the vicinity of the tree base as already reported by Kowalski \& Holdenrieder (2009b). Moreover, lenticels present at the tree collar are known to be efficient infection pathways through which spores of pathogens can penetrate and attack hosts (Garbelotto, 2004; Jung \& Blaschke, 2004). Further epidemiological studies on the relationship between quantification of apothecia and prevalence/severity of collar lesions would be useful to confirm this hypothesis.

Moist soil conditions were favourable for the development of collar bark lesions. These environmental conditions could be suitable for survival of $H$. pseudoalbidus on ash rachis in the litter and for apothecia production. In addition, the severity of collar bark lesions was higher in the youngest ashes, which could be linked to thinner bark on young trees. Although $H$. pseudoalbidus can affect all age classes of Fraxinus excelsior, highly infected young ash populations are commonly reported throughout central Europe (Skovsgaard et al., 2010). The prevalence of collar lesions was higher in the northeastern than the southwestern part of the study area. This disease gradient was probably due to a more recent arrival of the pathogen in the southwestern area. In France, the severe decline associated with $H$. pseudoalbidus was indeed first observed in the northeastern part of the study area in 2008 (Ioos et al., 2009). The higher prevalence of collar lesions with callusing older than a year in the northeast and the presence there of trees with 3-year-old callus are in agreement with an earlier arrival of the pathogen and suggest that $H$. pseudoalbidus was actually introduced several years before the first report in 2008.

A high frequency of Armillaria spp., A. gallica in particular, was observed in necrotic inner bark. This common species is widespread in hardwood forests as epiphytic rhizomorphs present on tree collars (Guillaumin et al., 1993; Marçais \& Caël, 2006). It has been shown to induce significant lesions only on trees weakened by other factors (Wargo \& Harrington, 1991; Sicoli et al., 2002; Prospero et al., 2004; Marçais \& Bréda, 2006). Armillaria cepistipes and A. gallica were commonly found from stem bases of declining or dead F. excelsior trees in Lithuania (Lygis et al., 2005; Bakys et al., 2011) and Denmark (Skovsgaard et al., 2010), respectively. Moreover, attacks of Armillaria spp. on ashes were never observed in $H$. pseudoalbidus-free plots, whereas $H$. pseudoalbidus was observed in one plot in which no Armillaria spp. were present. Undoubtedly, observed Armillaria spp. colonized tree collars weakened by the primary pathogen $H$. pseudoalbidus. However, they could play a more active role. Indeed, Armillaria and Phytophthora species were demonstrated to interact on oak trees infected by both pathogens to increase the damage (Marçais et al., 2011). Such a phenomenon between Armillaria and H. pseudoalbidus could accelerate the decline process of ash trees.

In the highly infected northeastern part of the study area, only $3 \%$ of ash trees were completely healthy, with neither crown decline nor collar lesions. This result would be consistent with the estimated prevalence of resistance to $H$. pseudoalbidus in the Danish ash population. Indeed, in an ash clone collection naturally infested by $H$. pseudoalbidus, $<5 \%$ were found to be resistant to the disease (McKinney et al., 2011).

Introduction of the pathogen to disease-free areas by transport of infected ash logs might be possible, as H. pseudoalbidus infection was frequent on the ash bole base and conidia were produced in laboratory conditions from these lesions. Although less frequent, H. pseudoalbi$d u s$ was also present on the bole on infected sprouts associated with small inner bark lesions. However, further studies are needed to prove that infected logs can disseminate $H$. pseudoalbidus. The ability of conidia to germinate either in vivo or in vitro has not yet been 
demonstrated. Therefore, the available data do not support control of ash log trade as a quarantine measure. However, current knowledge would suggest that trimming the lower infected parts of ash logs could be suggested to limit the putative dissemination risk.

\section{Acknowledgements}

The authors thank Axelle Andrieux, Lindsay Godard, Bruno Scala (INRA) and Nancy Jeangey (DSF) for technical assistance. This study was supported by grants from the Département de la Santé des Forêts.

\section{References}

Bakys R, Vasaitis R, Barklund P, Ihrmark K, Stenlid J, 2009. Investigations concerning the role of Chalara fraxinea in declining Fraxinus excelsior. Plant Pathology 58, 284-92.

Bakys R, Vasiliauskas A, Ihrmark K, Stenlid J, Menkis A, Vasaitis $\mathrm{R}, 2011$. Root rot, associated fungi and their impact on health condition of declining Fraxinus excelsior stands in Lithuania. Scandinavian Journal of Forest Research 26, 128-35.

Desprez-Loustau ML, 2009. The alien fungi of Europe. In: Drake JA, eds. DAISIE Handbook of Alien Species in Europe. Dordrecht, The Netherlands: Springer, 15-28.

European Plant Protection Organization, 2010. Chalara fraxinea, Ash Dieback. http://www.eppo.org/QUARANTINE/Alert_List/ fungi/Chalara_fraxinea.htm.

Garbelotto M, 2004. Sudden oak death: a tale of two continents. Outlooks on Pest Management 15, 85-9.

Guillaumin JJ, Mohammed C, Anselmi N et al., 1993. Geographical distribution and ecology of the Armillaria species in Western Europe. European Journal of Forest Pathology 23, 321-41.

Harrington TC, Wingfield BD, 1995. A PCR-based identification method for species of Armillaria. Mycologia 87, 280-8.

Husson C, Scala B, Caël O et al., 2011. Chalara fraxinea is an invasive pathogen in France. European Journal of Plant Pathology, 130, 311-24.

Ioos R, Kowalski T, Husson C, Holdenrieder O, 2009. Rapid in planta detection of Chalara fraxinea by a real-time PCR assay using a dual-labelled probe. European Journal of Plant Pathology 125, 329-35.

Jung T, Blaschke M, 2004. Phytophthora root and collar rot of alders in Bavaria: distribution, modes of spread and possible management strategies. Plant Pathology 53, 197-208.

Kirisits T, Matlakova M, Mottinger-Kroupa S, Halmschlager E, Lakatos F, 2010. Chalara fraxinea associated with dieback on narrow-leafed ash (Fraxinus angustifolia). Plant Pathology 59, 411.

Kowalski T, 2006. Chalara fraxinea sp. nov. associated with dieback of ash (Fraxinus excelsior) in Poland. Forest Pathology $36,264-70$.
Kowalski T, Holdenrieder O, 2008. A new fungal disease of ash in Europe. Schweizerische Zeitschrift für Forstwesen 159, 4550 .

Kowalski T, Holdenrieder O, 2009a. Pathogenicity of Chalara fraxinea. Forest Pathology 39, 1-7.

Kowalski T, Holdenrieder O, 2009b. The teleomorph of Chalara fraxinea, the causal agent of ash dieback. Forest Pathology 39, 304-8.

Lygis V, Vasiliauskas R, Stenlid J, 2005. Wood-inhabiting fungi in stems of Fraxinus excelsior in declining ash stands of northern Lithuania, with particular reference to Armillaria cepistipes. Scandinavian Journal of Forest Research 20, 337-46.

Marçais B, Bréda N, 2006. Role of an opportunistic pathogen in the decline of stressed oak trees. Journal of Ecology 94, 1214-23.

Marçais B, Caël O, 2006. Spatial pattern of the density of Armillaria epiphytic rhizomorphs on tree collar in an oak stand. Forest Pathology 36, 32-40.

Marçais B, Caël O, Delatour C, 2011. Interaction between root rot basidiomycetes and Phytophthora species on pedunculate oak. Plant Pathology 60, 293-303.

McKinney LV, Nielsen LR, Hansen JK, Kjær ED, 2011. Presence of natural genetic resistance in Fraxinus excelsior (Oleaceae) to Chalara fraxinea (Ascomycota): an emerging infectious disease. Heredity 106, 788-97.

Orlikowski LB, Ptaszek M, Rodziewicz A, Nechwatal J, Thinggaard K, Jung T, 2011. Phytophthora root and collar rot of mature Fraxinus excelsior in forest stands in Poland and Denmark. Forest Pathology 41, 510-9.

Prospero S, Holdenrieder O, Rigling D, 2004. Comparison of the virulence of Armillaria cepistipes and Armillaria ostoyae on four Norway spruce provenances. Forest Pathology 34, 1-14.

Queloz V, Grünig CR, Berndt R, Kowalski T, Sieber TN, Holdenrieder O, 2011. Cryptic speciation in Hymenoscyphus albidus. Forest Pathology 41, 333-42.

Robin C, Desprez-Loustau ML, Capron G, Delatour C, 1998. First record of Phytophthora cinnamomi on cork and holm oak in France and evidence of pathogenicity. Annales des Sciences Forestières 55, 869-83.

Schumacher J, Kehr R, Leonhard S, 2010. Mycological and histological investigations of Fraxinus excelsior nursery saplings naturally infected by Chalara fraxinea. Forest Pathology 40, 419-29.

Sicoli G, Annese V, De Gioia T, Luisi N, 2002. Armillaria pathogenicity tests on oaks in southern Italy. Journal of Plant Pathology 84, 107-11.

Skovsgaard JP, Thomsen IM, Skovgaard IM, Martinussen T, 2010. Associations between symptoms of dieback in even-aged stands of ash (Fraxinus excelsior L.). Forest Pathology 40, 7-18.

Wargo PM, Harrington TC, 1991. Host stress and susceptibility. In: Shaw CG, Kile GA, eds. Armillaria Root Disease. Washington, USA: Forest Service: USDA Agriculture Handbook No. 691, 88-101. 